\title{
Lumen
}

Selected Proceedings from the Canadian Society for Eighteenth-Century Studies

\section{The Spectator and Everyday Aesthetics}

\section{Brian Michael Norton}

Volume 34, 2015

URI : https://id.erudit.org/iderudit/1028515ar

DOI : https://doi.org/10.7202/1028515ar

Aller au sommaire du numéro

Éditeur(s)

Canadian Society for Eighteenth-Century Studies / Société canadienne d'étude du dix-huitième siècle

ISSN

1209-3696 (imprimé)

1927-8284 (numérique)

Découvrir la revue

Citer cet article

Norton, B. M. (2015). The Spectator and Everyday Aesthetics. Lumen, 34,

123-136. https://doi.org/10.7202/1028515ar d'utilisation que vous pouvez consulter en ligne.

https://apropos.erudit.org/fr/usagers/politique-dutilisation/ 


\title{
The Spectator and Everyday Aesthetics
}

\author{
Brian Michael Norton \\ California State University, Fullerton
}

It is generally acknowledged that our concepts of both art and the aesthetic are products of the Enlightenment. ${ }^{1}$ But the precise relation between these two concepts is less obvious than we may assume. The earliest aesthetic theorists-Shaftesbury, Joseph Addison, Francis Hutcheson-understood their subject to include more than just the newly grouped "fine arts," taking it to encompass aesthetic experience in the world at large as well as in the world of art. This capacious view of the aesthetic would prevail throughout the eighteenth century, up to and including Kant's third Critique (1790). There is broad agreement on these points. Nevertheless, we speak of aesthetic experience outside of art as if it were inherently derivative, secondary to the real aesthetic experience of artworks. This is true even of the most astute and insightful of commentators. Martin Jay, for example, in an essay subtitled

1. For studies of the emergence of "art" (or the "fine arts"), see Paul Oscar Kristeller, "The Modern System of the Arts: A Study in the History of Aesthetics (I)," Journal of the History of Ideas 12, 4 (1951): 496-527; Kristeller, "The Modern System of the Arts: A Study in the History of Aesthetics (II)," Journal of the History of Ideas 13, 1 (1952): 17-46; M. H. Abrams, "Art-as-Such: The Sociology of Modern Aesthetics," in Doing Things with Texts: Essay in Criticism and Critical Theory, ed. Michael Fischer (New York and London: W. W. Norton \& Company, 1989), 135-58; and Peter Kivy, "What Really Happened in the Eighteenth Century: The 'Modern System' Re-examined (Again)," British Journal of Aesthetics 52, 1 (2012): 61-74. For the emergence of "aesthetics," see Jerome Stolnitz, "On the Origins of "Aesthetic Disinterestedness," The Journal of Aesthetics and Art Criticism 20, 2 (1961): 131-43; Paul Guyer, "The Origins of Modern Aesthetics: 1711-35" in The Blackwell Guide to Aesthetics, ed. Peter Kivy (Oxford, Blackwell Publishing, 2008), 15-44; and Timothy M. Costelloe, The British Aesthetic Tradition: From Shaftesbury to Wittgenstein (Cambridge: Cambridge Univ. Press, 2013). 
"The Separation of Aesthetic Experience from the Work of Art," warns against this kind of "promiscuous aestheticization," characterizing it as an "indiscriminate leveling" of "artwork and lifeworld" through the "projection of qualities of the former onto the latter." Jay takes it for granted here that experiencing an object aesthetically means experiencing it as if it were an art object. We find something similar with David Marshall, another perceptive critic of the blurred boundaries of the aesthetic. "Once aesthetics is defined by a way of looking," Marshall writes, "the work of art becomes reinscribed in the world."” Marshall implies that with an aesthetic perspective we do not view our world aesthetically so much as we view it as art. While this certainly can be a component of everyday aesthetic experience, it does not define the experience as such. Passages like these grant art a primacy it did not possess in eighteenth-century aesthetic theory.

This essay decouples the aesthetic from the artwork to ponder the nature and significance of aesthetic experience in the world at large. My primary text is Joseph Addison and Richard Steele's Spectator, long recognized as a fountainhead of modern aesthetic thought. My methodology, however, will differ somewhat from typical accounts of the origins of aesthetics: rather than focusing exclusively on Addison, I will also be looking at the comparatively understudied figure of Steele; and rather than concentrating on essays devoted explicitly to literary and aesthetic themes, I will also be sifting those that deal with Mr. Spectator's experiences in and reflections on his natural and urban environments. Addison and Steele, I suggest, played a central, perhaps unrivalled role in developing and disseminating a way of looking that we would now identify as "aesthetic." This perspective is characterized by both a disengaged attitude toward the world and a heightened responsiveness to its beauty and wonder, allowing Mr. Spectator to find

2. Martin Jay, "Drifting into Dangerous Waters: The Separation of Aesthetic Experience from the Work of Art," in Aesthetic Subjects, ed. Pamela R. Matthews and David McWhirter (Minneapolis: Univ. of Minnesota Press, 2003), 18, 21.

3. David Marshall, The Frame of Art: Fictions of Aesthetic Experience, 1750-1815 (Baltimore: Johns Hopkins Univ. Press, 2005), 8.

4. Of course, the term "aesthetics" did not enter modern languages until later in the century through the work of Alexander Baumgarten. For a concise overview, see Costelloe, The British Aesthetic Tradition, 1-5. For a philosophical statement on the relation between art and the aesthetic, see Marcia Muelder Eaton, "Art and the Aesthetic," in The Blackwell Guide to Aesthetics, 63-77. 
value and satisfaction in the otherwise ordinary experiences of everyday life-a distinctly modern and affective conception of happiness that continues to resonate today. ${ }^{5}$ In its earliest phases, then, aesthetics did not designate a realm separate-or "autonomous"-from ordinary experience so much as it identified a mode of perception capable of enriching and enhancing that experience. ${ }^{6}$ Nevertheless, as this essay will also show, Addison and Steele's aesthetics was predicated on a kind of spectatorial distance or detachment that from the beginning was at odds with its own enhancive aims. In other words, even as aesthetic attention intensified ordinary experience, the logic of spectatorship also seemed to push the world away, a phenomenon to which Steele was particularly sensitive.

What we have come to think of as the quintessentially modern aesthetic perspective-detached, disinterested, non-purposivefinds its fullest early expression not in any philosophical treatise on art or aesthetics but in the everyday habits and inclinations of "Mr. Spectator," Addison and Steele's famous eidolon. Here is how Addison has Mr. Spectator introduce himself in the inaugural paper: "Thus I live in the World, rather as a Spectator of Mankind, than as one of the Species; by which means I have made my self a Speculative Statesmen, Soldier, Merchant and Artizan, without ever medling [sic] with any Practical Part in Life." ${ }^{7}$ Richard Steele, again in the guise of Mr. Spectator, would reaffirm these values in an essay published nearly a year and a half later: "To be ever unconcerned, and ever looking on new Objects with an endless Curiosity, is a Delight known

5. Aesthetics, as I am discussing it here, can be seen as part of the pragmatic "savoir vivre" Roy Porter taught us to see as a defining feature of the British Enlightenment. See Roy Porter, The Creation of the Modern World: The Untold Story of the British Enlightenment (New York and London: W. W. Norton and Co., 200o). For a critique of modern, affective happiness, see Vivasvan Soni, Mourning Happiness: Narrative and the Politics of Modernity (Ithaca and London: Cornell Univ. Press, 2010).

6. For "everyday aesthetics," see Yuriko Saito, Everyday Aesthetics (Oxford University Press, 2007), and Thomas Leddy, The Extraordinary in the Ordinary: The Aesthetics of Everyday Life (Broadview Press, 2012). Overlapping arguments can be found in Arnold Berleant, Art and Engagement (Philadelphia: Temple Univ. Press, 1991), and Richard Shusterman, Pragmatist Aesthetics: Living Beauty, Rethinking Art (Oxford: Blackwell, 1992). All of these philosophers draw on John Dewey, Art as Experience ([1934] New York: Perigee, 2005).

7. Joseph Addison and Richard Steele, The Spectator, ed. Donald Bond, 5 vols. (Oxford: Clarendon, 1965), 1:4; hereafter cited parenthetically. 
only to those who are turned for Speculation: Nay, they who enjoy it, must value things only as they are the Objects of Speculation, without drawing any worldly Advantage to themselves from them ..." (S 4:98). As his name suggests, Mr. Spectator practices a spectatorial form of engagement with the world, looking upon it as if from the outside, and doing so, significantly, without any thought of practical interest or gain. He is a "Spectator of Mankind," rather than "one of the Species," observing society "without ever medling with any Practical Part in Life"; "ever looking on new Objects," he takes from them a "Delight" that is distinct from "any worldly Advantage." The frame of mind Addison and Steele are fashioning here would in time come to be identified with the aesthetic as such, finding clear echoes, for example, in Edward Bullough's "aesthetic distance" and Jerome Stolnitz's disinterested "aesthetic attitude." summary, the modern aesthetic perspective is understood to be "contemplative, passive, and spectatorial, distancing the self from the world and our appetite to possess or consume it." ${ }^{9}$ Nowhere in the period are these qualities articulated more influentially than in the character of Mr. Spectator.

With this mindset Mr. Spectator is able to transform his surroundings into an arena of aesthetic experience. As Addison proclaims in the first of his celebrated papers on the "Pleasures of the Imagination" (Spectators 411-21), the individual of "Polite Imagination" "looks upon the World, as it were, in another Light, and discovers in it a Multitude of Charms, that conceal themselves from the generality of Mankind," allowing the spectator to feel "a greater Satisfaction in the Prospect of Fields and Meadows, than another does in the Possession" (S 3:538). It is worth noting that this passage, which has become a locus classicus of modern aesthetic theory, was anticipated by Steele's claim in Tatler 89 that the "right Frame of Mind raises that sweet Enthusiasm which warms the Imagination at the Sight of every Work of Nature, and turns all around you into Picture and Landskip." With this "Frame of Mind," Steele suggests, one is capable of "enjoying the World in the Simplicity

8. Edward Bullough, “Psychical Distance' as a Factor in Art and as an Aesthetic Principle," British Journal of Psychology 5, 2 (1904): 87-118; Jerome Stolnitz, Aesthetics and Philosophy of Art Criticism: A Critical Introduction (New York: Houghton Mifflin, 1960).

9. Jay, "Drifting into Dangerous Waters," 11. 
of its natural Beauties."10 What Addison and Steele are both suggesting in these passages is that a special form of attention makes it possible to find value even in ordinary things and experiences. Indeed, it is precisely the commonplace-ubiquitous, universal, endlessly renewablethat is best suited to this alchemical process. As Steele puts it, "The Air, the Season, a Sun-shine Day, or a fair Prospect, are Instances of Happiness, and that which [one] enjoys in common with all the World ... are to him uncommon Benefits and new Acquisitions" (S 2:309). Such an individual has no need "for any thing extraordinary to administer Delight to him" (S 2:309); for him, Addison explains in a later essay, the "whole Universe is a kind of Theatre filled with Objects" supplying "Pleasure, Amusement, or Admiration" (S 3:453).

Such affective experience plays a vital role in modern conceptions of happiness and personal well-being. Today many of us take it for granted that we can fundamentally enrich life simply by increasing our awareness of and receptivity to the ordinary beauty around us. The idea is central to a good deal of post-Enlightenment thought, running from William Wordsworth to the Transcendentalists, from Walter Pater to the high modernists, from John Dewey to contemporary philosophers like Richard Shusterman, Arnold Berleant, Thomas Leddy, and Sherri Irvin, all of whom have highlighted the value of aesthetic experience outside of art. For Wordsworth, of course, this was an abiding theme: "Thus daily were my sympathies enlarged, / And thus the common range of visible things / Grew dear to me." Wordsworth goes on in this same passage to describe the sun as "a light / Which while we view we feel we are alive."ll This kind of heightened responsiveness to the world's ephemeral beauty is precisely what Pater intended with his memorable line, "To burn always with this hard, gemlike flame, to maintain this ecstasy, is success in life." ${ }^{2}$ More recently, the philosopher Sherri Irvin has argued that "our everyday lives" have a thoroughly "aesthetic character," should "we choose to attend to it." ${ }^{3}$ Her

10. Joseph Addison and Richard Steele, The Tatler, ed. Donald F. Bond, 3 vols. (Oxford: Clarendon Press, 1987), 2:59-60.

11. William Wordsworth, The Prelude, ed. J. C. Maxwell (London: Penguin Books, 1986), II.181-83, II.185-86.

12. Walter Pater, The Renaissance: Studies in Art and Poetry, in Selected Writings of Walter Pater, ed. Harold Bloom (New York: Columbia Univ. Press, 1974), 60.

13. Sherri Irvin, "The Pervasiveness of the Aesthetic in Ordinary Experience," British Journal of Aesthetics 48, 1 (2008): 30. 
examples are scrupulously mundane, and for that reason striking: "Being in the room you are in right now ... feeling the air current on your skin"; walking down a dirt road, contemplating the "subtle patterns" of the tire tracks; drinking tea out of a large "roughly eggshaped" mug clasped between one's warming palms. ${ }^{14}$ These otherwise uneventful moments of daily life, she insists, are potentially deep sources of gratification: "If we attend to the aesthetic aspects of everyday experience, our lives can come to seem more satisfying to us, even more profound." 15 While such thinking is widespread in modern culture, the Enlightenment origins of this idea remain largely unacknowledged and little understood.

Addison and Steele, as we have noted in the above passages, held everyday aesthetic experience to be charged with positive affect, variously describing the latter as "Delight," "Satisfaction," "Pleasure," and "Happiness." It is important here to not confuse philosophical disinterestedness with the ordinary sense of being uninterested. ${ }^{16}$ Mr. Spectator is vitally interested in everything he surveys, but his interest, to use a later terminology, is intrinsic to the experience ("for its own sake") rather than extrinsic to it ("instrumental"). At any rate, there is no question he finds it enriching. Precisely how this is the case is something Addison and Steele explain in markedly different ways.

Addison frequently couches his discussions of aesthetics in the language of theology-or, more precisely, in the physico-theology of writers like John Ray and William Derham. ${ }^{17}$ Like them, Addison proceeds from the empirical observation of Nature to advance teleo-

14. Irvin, "The Pervasiveness of the Aesthetic," 30-31.

15. Irvin, "The Pervasiveness of the Aesthetic," 41.

16. The key treatment of disinterestedness remains Stolnitz, "On the Origins of "Aesthetic Disinterestedness." See also Paul Guyer, "The Dialectic of Disinterestedness: I. Eighteenth-Century Aesthetics," in Kant and the Experience of Freedom: Essays on Aesthetics and Morality (Cambridge: Cambridge Univ. Press, 1993), 48-93. For a lively debate over the merits of disinterestedness, see Arnold Berleant and Ronald Hepburn, "An Exchange on Disinterestedness," Contemporary Aesthetics 1 (2003): http://hdl.handle.net/2027/sp0.7523862.0001.007. For a critique of Stolnitz, see George Dickie, "The Myth of the Aesthetic Attitude," American Philosophical Quarterly 1, 1 (1964): 56-65.

17. More than 20 years ago, Lisa Zeitz observed the links between Addison's aesthetics and physico-theology, a relationship that deserves much more scholarly attention than it has received to date. See Lisa M. Zeitz, "Addison's 'Imagination' Papers and the Design Argument," English Studies: A Journal of English Language and Literature 73, 6 (1992): 493-502. 
logical arguments about its design, purposes, and creator. Readers of the "Imagination" papers will recall that Addison characterizes the "Beautiful," the "New," and the "Great" in terms of their "Final Causes," that is, their purpose or aim as intended by the "first Contriver": Beauty leads creatures "to multiply their Kind"; the Uncommon encourages us "in the pursuit after Knowledge"; and the Great kindles in us habits of "Devotion" that will ultimately be satisfied in the divine "Contemplation of his Being." In the same paper, Addison proposes that the "Supreme Author" "has given almost every thing about us the Power of raising an agreeable Idea in the Imagination," making it "impossible for us to behold his Works with Coldness or Indifference" or "to survey so many Beauties without a secret Satisfaction and Complacency" (S 3:545-6). In a later essay, Addison extrapolates from the sheer fact of these "Beauties" a kind of aesthetic version of the argument from design, postulating that "Faith and Devotion naturally grow in the Mind of every reasonable Man, who sees the Impression of Divine Power and Wisdom in every Object on which he casts his Eye," concluding that the "Supream [sic] Being has made the best Arguments for his own Existence, in the Formation of the Heavens and the Earth" (S 4:144). ${ }^{18}$ To appreciate the world's aesthetic splendors, then, is for Addison an inherently spiritual, even reverential act, an idea he elaborates in three consecutive Saturday essays on "Chearfulness." If "Providence" has so ordered things that we are "cheared and delighted" by almost everything we hear and see ( $S$ 3:453), Addison reasons, then this "inward Chearfulness" is itself a form of "implicit Praise and Thanksgiving" (S 3:430) or, at the very

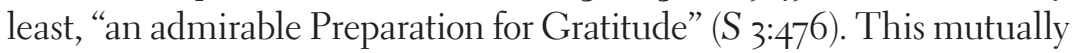
reinforcing commerce between a cheerful mind and beautiful world ideally produces an "habitual Disposition" that "consecrates every Field and Wood, turns an Ordinary Walk into a Morning or Evening Sacrifice," and consolidates "transient Gleams of Joy" into a "perpetual State of Bliss and Happiness" (S 3:476). Such is Addison's account of the extraordinary value of everyday aesthetic experience.

Steele presents a very different understanding of these matters. Rather than drawing on the discourses of science and theology, as Addison does, Steele formulates a conception of ordinary and aesthetic

18. Zeitz, “Addison's 'Imagination' Papers and the Design Argument," 497. 
experience that is strikingly existential in character. According to Steele, the greater part of what "we ordinarily call our Life" is passed in "Instances of Inexistence," a concept that anticipates Virginia Woolf's notion of the "cotton wool" of "non-being" (S 1:420, 1:421). ${ }^{19}$ We spend most of our lives, Steele was convinced, not fully awake to life, not fully alive. "A Man advanced in Years that thinks fit to look back upon his former Life," he writes, "and calls that only Life which was passed with Satisfaction and Enjoyment, ... will find himself very young, if not in his Infancy" (S 1:419). As Steele proclaims in another essay, using the term that will become Addison's theme in the Saturday papers cited above, "There is no real Life, but chearful Life" ( $\left.S_{2}: 65\right)$. It is in the context of this impoverished state of being, this chronic "Inexistence," that Steele advises us to "preserve a Disposition in our

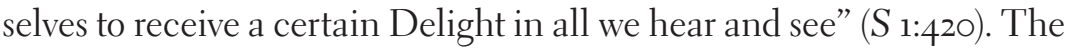
value of the aesthetic attitude, as Steele conceptualizes it, lies in its potential to intensify ordinary experience, attaching us to the living present and awakening us to life. Through this "Disposition" to "Delight in all we hear and see," Steele argues, we can live in such a way that "there are no Moments lost" and the "heaviest of Loads (when it is a Load) that of Time, is never felt by us" (S 1:421). ${ }^{20}$ Like Addison, Steele ascribes tremendous value to everyday aesthetics, but he offers a more rigorously secular interpretation of how it contributes to the "Satisfactions of [our] Being" (S 1:420). ${ }^{21}$

19. Woolf writes: "Every day includes much more non-being than being. . . A great part of every day is not lived consciously." Virginia Woolf, Moments of Being, ed. Jeanne Schulkind. $2^{\text {nd }}$ ed. (San Diego: A Harvest Book, 1985), 70.

20. For a superb treatment of "time" in Addison and Steele's periodical, see Stuart Sherman, Telling Time: Clocks, Diaries, and English Diurnal Form, 1660-1785 (Chicago and London: Univ. of Chicago Press, 1996), 109-58. Sherman finds in the papers "a running argument in favor of a diurnal paradigm for achieving, recognizing, and inhabiting the fullness of time." Sherman, 115.

21. Scott Black makes a strong argument for the ultimately secular nature of Addison's aesthetics in "Addison's Aesthetics of Novelty," Studies in EighteenthCentury Culture 30 (2001): 269-88. I would suggest that Addison's aesthetics offers an experience of "fullness" (to use Charles Taylor's terminology) that is at first understood with reference to the divine but which established practices and sensibilities that will go on to outlast its theological scaffolding. Steele's aesthetics (how rarely we hear that phrase!) provides an early example of how this is done. For his magisterial account of secularism, see Charles Taylor, A Secular Age (Cambridge: Harvard Univ. Press, 2007). 
By examining Addison and Steele's rich musings on the nature and significance of aesthetic experience in the world outside of art-here at the very inception of aesthetic theory-I hope to shed light on the largely forgotten origins of ideas and practices we more readily identify with rural sages and urban aesthetes of later eras. I also aim to underscore the extent to which early aesthetic theory was dedicated to thinking about the ordinary and the everyday. What I do not intend is a wholesale endorsement of Addison and Steele's ideas, as if modern aesthetics could overcome its own problems by merely returning to its founding principles. To argue for such an uncritical "return" is as simplistic and one-sided as blaming "the Enlightenment" for everything that ails the modern world. Addison and Steele's aesthetics had drawbacks and limitations of its own, which Steele himself seems to have recognized. Throughout the series we can see him occasionally chafing against the constraints of pure spectatorship, as if he hungered for a more immediate and full-bodied encounter with the world. Such is evident in his great essay on roving London for "Four and twenty Hours" (S 454).

Steele begins Spectator 454, as quoted above, by reiterating the spectatorial values of "ever looking on new Objects" and looking on them strictly insofar as they are "Objects of Speculation." This is also where Mr. Spectator declares that "the greatest Pleasure I know I receive at my Eyes" (S 4:98). ${ }^{22}$ Michael Ketcham has described this essay as "The Spectator in epitome," and indeed I think it encapsulates the considerable resources as well as the ultimate weaknesses of Addison and Steele's spectatorial aesthetics. ${ }^{23}$ The bulk of the essay is taken up with Mr. Spectator's history of a single, ordinary day in the capital. Being "restless" one night, he "arose at Four in the Morning, and took Boat for London, with a Resolution to rove by Boat and Coach for the next Four and twenty Hours, till the many different Objects I must needs meet with should tire my Imagination" (S 4:98). Under his

22. For two recent studies that draw attention to the embodied nature of "vision" in the Spectator, see Kathleen Lubey, "Erotic Interiors in Joseph Addison's Imagination," Eighteenth-Century Fiction 20, 3 (2008): 415-44; and Manushag N. Powell, "See No Evil, Hear No Evil, Speak No Evil: Spectation and the Eighteenth-Century Public Sphere," Eighteenth-Century Studies 45, 2 (2012): 255-76. As I am suggesting here, these arguments are even truer of Steele than they are of Addison.

23. Michael Ketcham, Transparent Designs: Reading, Performance, and Form in the Spectator Papers (Athens: Univ. of Georgia Press, 1985), 84. 
attentive gaze, London unfolds into a series of captivating scenes and charming landscapes, populated by a colorful array of "Fruit-Wenches," "Morning Rakes," "Chimney-Sweepers," Covent Garden "Purveyors," "Coachmen," "Ladies," "Silk-Worms," "Tradesmen," "Ballad Singers," and "People of Fashion." "As I drove along," Mr. Spectator recounts, "it was a pleasing reflection to see the World so prettily checquer'd" (S 4:101). Steele's portrait of urban life is much closer in spirit to the aestheticized realism of Laurence Sterne's A Sentimental Journey (1768) than it is to the gritty satire of Jonathan Swift's "Description" poems (1709; 1710) or the more ambiguous case of John Gay's Trivia: or, the Art of Walking the Streets of London (1716), which, like Steele's Spectator essay, can be read as an early experiment in flanerie. Though there are moments of undeniable beauty in Gay's poem-the depiction of the frozen Thames, for instance-Gay does not concern himself with the experience of beauty in the same way Steele and Sterne do. ${ }^{24}$ Steele's essay not only follows Mr. Spectator through an aesthetically interesting environment, it is about aesthetic experience. And, consistent with Addison and Steele's more abstract statements on aesthetics, this is shown to be affectively charged in ways that are both profound and hard to account for.

Here, for example, is how Mr. Spectator attempts to make sense of his experience at the Exchange:

As other Men in the Crowds about me were pleased with their Hopes and Bargains, I found my Account in observing them, in Attention to their several Interests. I, indeed, look'd upon my self as the richest Man that walk'd the Exchange that Day; for my Benevolence made me share the Gains of every Bargain that was made. (S 4:102)

Anthony Pollock, flagging the metaphors deployed in this passage, remarks that "Mr. Spectator never really distances himself from the language and practices of economics." While Pollock ultimately reads this in terms of "neutrality's impossibility," ${ }^{25}$ I would suggest that

24. For a study of aesthetic experience in A Sentimental Journey, see Brian Michael Norton, "Laurence Sterne and the Aesthetics of Everyday Life," in Sterne, Tristram, Yorick: Tercentenary Essays on Laurence Sterne, ed. Peter de Voogd, Judith Hawley, and Melvyn New (Newark: Univ. of Delaware Press, 2015).

25. Anthony Pollock, Gender and the Fictions of the Public Sphere, 1690-1755 (New York: Routledge, 2009), 66. In recent decades, scholarly readings of the Spectator have frequently taken the form of ideological critique. For the best of this 
Steele's language deliberately recalls Addison's earlier claim that "the Prospect of Fields and Meadows" gives the aesthetic spectator "greater Satisfaction" than another finds in their "Possession," a passage that also notably explains, "It gives him, indeed, a kind of Property in every thing he sees" (S 3:538). Addison and Steele in these passages are working out (however awkwardly) the aesthetic concept we now recognize as disinterested pleasure. ${ }^{26}$ Of course, disinterestedness in any form was and remains a contested topic, but Addison and Steele here are taking an early and momentous step in applying the concept to aesthetics. What is perhaps even more remarkable-and modern-about Steele's formulation is that he tries this out not in God's providentially ordered Nature but in man's bustling and chaotic Town. When Steele finally has Mr. Spectator return home to write "these Minutes," he confesses he is "at a Loss what Instruction I should propose to my Reader." But he insists that if his readers learn to "keep their Minds open to Gratification," they too can transmute the "insignificant Matters and Occurrences" of a "trivial Day" into lasting feelings of "Satisfaction" and "Happiness" (S 4:103).

At the same time, however, Mr. Spectator is unusually "restless" in this essay, as if he were not entirely content to float through life as a mere "Looker-on." Under Steele's pen, he appears ready to slough off the guise of spectatorial detachment, which was always a better fit for the equable Addison than for the high-spirited Steele. ${ }^{27}$ Mr. Spectator seems to crave greater contact with the world.

work, see (in addition to Pollock), Carole Fabricant, "The Aesthetics and Politics of Landscape in the Eighteenth Century," in Studies in Eighteenth-Century British Art and Aesthetics, ed. Ralph Cohen (Berkeley and Los Angeles: Univ. of California Press, 1985), 49-81; Erin Mackie, Market à la Mode: Fashion, Commodity, and Gender in The Tatler and The Spectator (Baltimore and London: Johns Hopkins Univ. Press, 1997); and Scott Paul Gordon, The Power of the Passive Self in English Literature, 1640-1770 (Cambridge: Cambridge Univ. Press, 2002), chap. 3.

26. As Ronald Paulson puts it, "Addisonian disinterestedness is based not on property ownership but (a truer disinterestedness) on not owning land ..." Ronald Paulson, The Beautiful, Novel, and Strange: Aesthetics and Heterodoxy (Baltimore and London: Johns Hopkins Univ. Press, 1996), 74.

27. For an illuminating look at the way nineteenth-century critics understood the stylistic differences between the two essayists, see Brian McCrea, Addison and Steele are Dead: The English Department, Its Canon, and the Professionalization of Literary Criticism (Newark: Univ. of Delaware Press, 1990), chap. 4. 
After explaining that it is his usual custom to travel by coach because his "unhappy Curiosity" is such that some "odd Adventure among Beggars, Ballad Singers, or the like, detains and throws [him] into Expence," Mr. Spectator nevertheless decides to try his luck on foot. As it turns out, he is "immediately" accosted in this fashion. Lingering at the corner of "Warwick-Street" to listen to a new ballad, a "Beggar" he knows asks him for a six-pence to buy ale, wittily claiming that "all his Family had died of Thirst" ( $S_{4: 101)}$. When the crowd begins to turn their "Eyes" on Mr. Spectator (who claims elsewhere that being "stared at" is the "greatest pain" he can suffer), we suspect that this time he is reluctant to leave them. Forced back into the cloistered safety of another coach, Mr. Spectator resumes his journey into the heart of things, with "his Joy still rising till we came into the Centre of the City, and the Centre of the World of Trade, the Exchange of London" (S 4:102). If Steele's eidolon seems to anticipate Sterne's Yorick in his "odd Adventure[s]" among the urban poor, the resemblance grows stronger at the Exchange as we see him loiter in the "Shops of agreeable Females," observing "so many pretty Hands busie in the Foldings of Ribbands," where "I should longer have indulged my self, had not the dear Creatures called to me to ask what I wanted, when I could not answer, only To look at you" (S 4:102). There is something equivocal, of course, about Mr. Spectator's non-answer, hovering as it does between two poles of impossibility: he cannot respond this way because either a) it would be impolite, or b) it would not be true. Either way, Mr. Spectator's posture of detachment does not allow for the kind of tactile, intersubjective engagement that will define Yorick's commerce with the world. Much to Steele's chagrin, Mr. Spectator only gets to watch.

An even more revealing moment occurs at the Exchange when Mr. Spectator finds himself looking through an open window at the crowded life below, "where all the several Voices lost their Distinction, and rose up in a confused Humming." As in the carriage ride into the City, a window frames the aesthetic field, and marks his separateness from it. The scene produces in him a "Reflection," which, he claims, would not occur to any but one "a little too serious": "What Nonsense is all the Hurry of this World to those who are above it?" (S 4:102). We would expect this moment to mark a triumph of disinterested spectatorship, with Steele's eidolon achieving here the very freedom 
from the "Nonsense" and "Hurry" of the world that Addison and Steele had been advocating throughout their series. ${ }^{28}$ But something rather different occurs. Mr. Spectator immediately seems to regret the "Pun" and the strained attempt at wisdom, as if he were embarrassed by his own feelings of aloof superiority. His very next line is intentionally, skillfully bathetic, signaling his desire to reenter the world he surveys: "In these, or not much wiser Thoughts, I had like to have lost my Place at the Chop-House" (S 4:102). ${ }^{29}$ The aesthetic attitude Addison and Steele did so much to forge made it difficult to simultaneously spectate and participate in life; or, as one of their letter writers described this "Paradox," to "live in the World, and out of it, at the same time" (S 1:115). Disinterestedness demands a kind of apartness. Martin Jay, who, as I noted above objects to the very idea of everyday aesthetics, explains the point this way: "We are no longer immersed in being-inter-esse, as the etymology of the word interest suggests-but rather somehow outside it." ${ }^{30}$ Mr. Spectator is able to transform his surroundings into a rich, vast, almost limitlessly varied aesthetic field. But the cost of doing so, as I believe Steele recognized, is to place the world at a certain remove.

Like other thinkers of the period, Addison and Steele understood aesthetic experience to be something that occurs in the wider world, not just in art, and they were especially interested in the aesthetic's capacity to enrich and intensify the experience of everyday life. Such efforts to find beauty and value in the ordinary would later become central to modern aesthetic practices, both in and outside of art. But, as we have also seen, these aims were undermined by the very aesthetic model Addison and Steele helped create: that of the detached, disengaged spectator. Recent decades have witnessed widespread efforts in philosophy, in both continental and analytic traditions, to find a replacement for this aesthetic model, one that is more multisensory,

28. As Ketcham puts it, Steele writes about "the man in common life whose retirement is not a removal from the world but a disinterestedness sustained within it." Ketcham, Transparent Designs, 29.

29. Contrasting Addison with Ned Ward, Pollock observes that "Addison specializes in mezzanine-level speculation about aestheticized matters of commerce and taste that always hovers at an unmistakable remove 'above' the things and people it views." Pollock, Gender and the Fictions of the Public Sphere, 42. The reading I am elaborating here highlights Steele's ambivalence about this Addisonian practice.

30. Jay, "Drifting into Dangerous Waters," 9. 
embodied, and immersive. But, of course, alternative aesthetic paradigms were present all along. Indeed, one such alternative can be found in the aesthetic interest Steele takes in "Air" and "Sun-shine" and the "Season": rather than standing apart from the aesthetic field, as we do in the spectator model, here we are enveloped by it. In his "Chearfulness" essays, Addison himself speaks of the "Tastes and Colours, Sounds and Smells, Heat and Cold," by which the "Mind" is "cheared and delighted with agreeable Sensations" (S 3:453), proposing that the attentive individual "tastes all the Pleasures of the Creation which are poured about him" (S 3:430). ${ }^{31}$ Whether or not such multisensory experience could avoid the problems of spectatorship is a question this essay will leave open. Whatever the case, this paradigm was not embraced by the main currents of eighteenth-century aesthetic theory. ${ }^{32}$ And if today there is a growing consensus that the immersive, multisensory model is preferable to the spectatorial one, the former says as much about our moment as the latter does about the Enlightenment.

31. Powell highlights multisensory elements in the Spectator in "See No Evil, Hear No Evil, Speak No Evil," 257-63. For additional recent work on sensory experience in the eighteenth century, see Manushag N. Powell and Rivka Swenson's "Sensational Subjects," a special issue of The Eighteenth Century: Theory and Interpretation 54, 2 (2013).

32. Paralleling the work of theorists and philosophers, literary historians devote increasing attention to these alternatives. Ronald Paulson, for example, reconstructs a "countertradition" to mainstream aesthetic thought in The Beautiful, Novel, and Strange, xi; and David Marshall tells the story of a "counterplot" to the dominant narrative in The Frame of Art: Fictions of Aesthetic Experience, 1750-1815 (Baltimore: Johns Hopkins Univ. Press, 2005), 2. 